\title{
PURIFICATION OF RAVE COMPLEX FROM Saccharomyces cerevisiae USING FLAG TAG-AFFINITY PURIFICATION METHOD
}

\author{
Nguyen Thanh Chung ${ }^{1}$ *, Pham Thi Tam ${ }^{1}$, Ta Thi Thu Thuy ${ }^{1}$, Chunyin Gu$^{2}$, \\ Zhenyu Zhang ${ }^{2}$ \\ ${ }^{1}$ Faculty of Biotechnology, Hanoi Open University, Hanoi, Vietnam \\ ${ }^{2}$ The Key Laboratory of Industrial Biotechnology, Jiangnan University, China \\ *Email:ngthachung@gmail.com
}

Received: 25 December 2012; Accepted for publication: 7 November 2013

\begin{abstract}
RAVE (Regulator of the $\mathrm{H}^{+}$-ATPase of the Vacuolar and Endosomal membranes) is an essential factor of assembly and reversible disassembly of V-ATPase. RAVE complex has three subunits, which are Rav1p, Rav2p and Skp1p. There are few studies on RAVE so it is very important to study structure of RAVE complex to understand more about the regulation of the assembly and reassembly at V-ATPase. In this study the RAVE complex was purified by affinity purification by fussing FLAG tag to subunit Rav1p or Rav2p. Experimental process: yeast cells were incubated in $8 \mathrm{~L}$ YEPD medium at $30^{\circ} \mathrm{C}, 200 \mathrm{rpm}\left(\mathrm{OD}_{600 \mathrm{~mm}}\right.$ around of 3). Furthermore harvested cells were broken by a French pressure cell disruptor at 25,000 p.s.i in TBSE (50 mM Tris/Cl, $150 \mathrm{mM} \mathrm{NaCl}, 1 \mathrm{mM}$ EDTA, $\mathrm{pH}$ 7.4) with $1 \mathrm{~mm}$ PMSF. The cell lysate was centrifuged at $20,000 \mathrm{xg}$ for 20 minutes at $4{ }^{\circ} \mathrm{C}$. Then, the supernatant, was achieved by centrifugation, and loaded onto a small column contained $1 \mathrm{ml}$ of anti-FLAG M2 gel. After washing anti-FLAG column with TBSE, RAVE complex was eluted with TBSE containing $100 \mu \mathrm{g} / \mathrm{ml}$ FLAG peptides. The results showed RAVE complex purification from strain with FLAG tag fused in C-terminus of Rav2 is better than RAVE complex purification from the yeast strain S. cerevisiae with FLAG tag fused in N-terminus of Rav1 or C-terminus of Rav1.
\end{abstract}

Keywords: RAVE complex, Rav1, Rav2, Skp1, V-ATPase, Yeast, protein purification.

\section{INTRODUCTION}

In eukaryotic cells, Vacuolar proton-translocating ATPases (V-ATPases) are present in organelles, such as endosomes, lysosomes, Golgi-derived vesicles, secretory vesicles and the plasma membrane of some cells. V-ATPase plays a central role in acidification of these organelles $[1,2,3,4]$. And it plays a key role in many normal and disease processes such as regulation of the vacuolar fission-fusion equilibrium [5], neurotransmitter release [6], endocytic and secretory trafficking [7], ovulation and embryogenesis [8], virus infection [9], cancer [10, 11] 
and Alzheimer disease [12]. Therefore the studies about the structure, mechanism and regulation of V-ATPase are very important with several studies on structure, function and regulation being done with $S$. cerevisiae due to the ease of incubation and gene manipulation.

The V-ATPase is a lagre, multi-subunit enzyme and composes of two domains $\mathrm{V}_{1}$ and $\mathrm{V}_{0}$. The $\mathrm{V}_{1}$ domain is a peripheral complex of $650 \mathrm{kDa}$, consists of eight different subunits named $\mathrm{A}$, $\mathrm{B}, \mathrm{C}, \mathrm{D}, \mathrm{E}, \mathrm{G}$ and $\mathrm{H}$ with molecular weight $13-70 \mathrm{kDa}$. It hydrolyzes ATP to ADP, Pi and releases energy. The $\mathrm{V}_{0}$ domain is an integral complex of $260 \mathrm{kDa}$ includes six different subunits as a, d, e, c, c' and c' of molecular mass 9-100 kDa. The energy released in ATP hydrolysis is transferred to the $\mathrm{V}_{0}$ domain to drive protons translocation from cytoplasm to the lumen or extracellular space $[1,2,13,14,15,16]$.

Many studies in yeast V-ATPase were carried out, but until now the regulation of VATPase is not completely understood [2, 14, 17, 18, 19]. A few years ago, a novel factor was found which played an important role in both assembly of V-ATPase and reassembly of disassembled $\mathrm{V}_{1}$ and $\mathrm{V}_{0}$ domains, was named the RAVE complex (Regulator of the $\mathrm{H}^{+}$-ATPase of the Vacuolar and Endosomal membranes), includes Rav1p, Rav2p and Skp1p [17, 18, 19]. Skp1p subunit has molecular weight about $22 \mathrm{kDa}$ and is also a subunit of SCF ubiquitin ligases. The molecular weight of Rav2p is $40 \mathrm{kDa}$ and Rav1p is $155 \mathrm{kDa}$ [17, 20, 21, 22]. In RAVE complex, Rav1p binds to Rav2p and Skp1p, but Rav2p do not bind to Skp1p. When RAVE complex regulates for assembly and reassembly of this enzyme, RAVE complex binds to $\mathrm{V}_{1}$ sector at subunits $\mathrm{E}$ and $\mathrm{G}$ [17]. Further, RAVE can affect the efficient assembly of $\mathrm{C}$ subunit with the V-ATPase. In absence of RAVE complex, in the regulation of V-ATPase, the subunit C is not stable with the V-ATPase [19]. The topology and V-ATPase's regulation of the RAVE complex is shown in Fig. 1. It is very important to study the structure of RAVE complex to understand the regulation of V-ATPase. Therefore, in this study, we want to purify RAVE complex for further study.

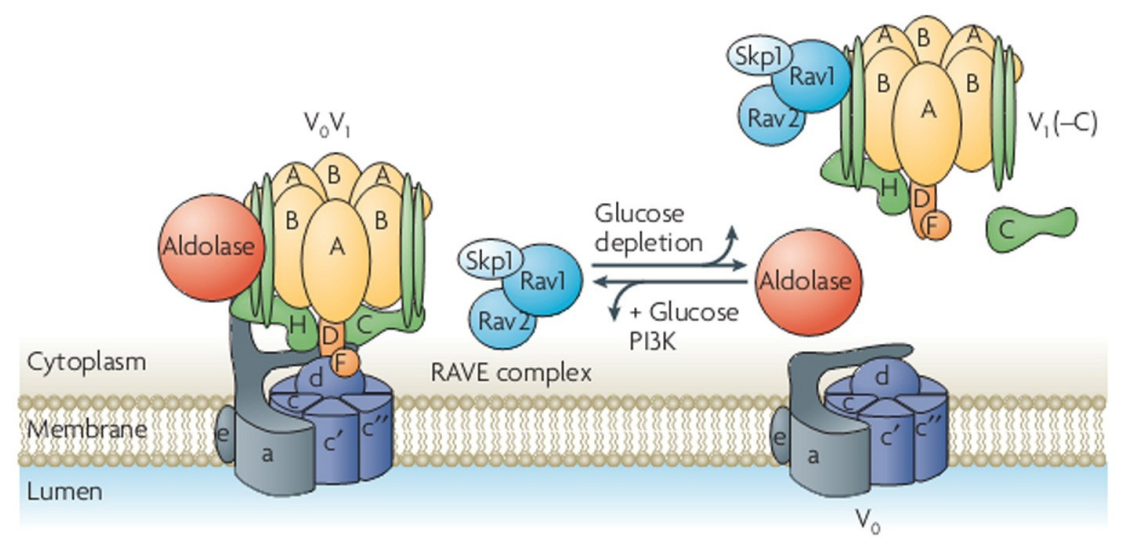

Figure 1. Models for RAVE activity in assembly and reassembly of disassembly of the V-ATPase [2].

\section{MATERIALS AND METHODS}

\subsection{Reagents and growth media}

Oligonucleotides (table 1), herring sperm ssDNA and DNA marker S plus were synthesized by Sangon Biotech (Shanghai) Co. Ltd. Taq DNA polymerase, pfu DNA polymerase, dNTP, agarose, Tris base, EDTA, phenylmethylsulfonyl fluoride, yeast extract, peptone and G418 were purchased from Bio Basic Inc. Lyticase, Anti-FLAG M2 Affinity gel and FLAG peptide were 
purchased from Sigma-Aldrich Shanghai Trading Co Ltd. Anti-FLAG Tag Monoclonal Antibody and HRP AffiniPure Goat Anti-Mouse IgG were purchased from EarthOX. 0.45 $\mu \mathrm{m}$ PVDF membrane was purchased from Millipore. GeneRuler $1 \mathrm{~kb}$ DNA Ladder and PageRuler Prestained Protein Ladder were purchased from Fermentas. All other chemicals and reagents, were not noted, were from Sinopharm Group Co.Ltd. Yeast cells were grown in $1 \%$ yeast extract, $2 \%$ peptone and $2 \%$ dextrose (YEPD) medium at $30{ }^{\circ} \mathrm{C}$. For growth of recombinant strains, YEPD was contained $2 \%$ agar and added G418 to the final concentration of it is $200 \mu \mathrm{g} / \mathrm{ml}$.

\subsection{Strains}

The two strains were used in this study are Saccharomyces cerevisiae BY4742 from State Key Laboratory of Food Science and Technology of Jiangnan University and S. cerevisiae SF838-5A RAV1-Myc13 2.3 from Patricia Kane in the Department of Biochemistry and Molecular Biology, State University of New York, Upstate Medical University.

\subsection{Strain Construction}

Flag tag was fused to the N-terminus of Rav1, C-terminus of Rav1 and C-terminus of Rav2. Using S. cerevisiae BY4742 genome for synthesizing the fragments are homogeneous with yeast genome. S. cerevisiae genome was used for synthesizing KanMX6 marker. For fragments have length less than 1,000 bp in length, Taq DNA polymerase was used to run PCR. For the fragments have length more than 1,000 bp in length, Taq and pfu DNA polymerase were used to run PCR. Fusion PCR was also used Taq and $p f u$ DNA polymerase. Primers from YNR1-1 to YNR1-8 were used to construct FLAG tag to N-terminus of Rav1, primers from YCR1-1 to YCR1-4 were used to construct FLAG tag to C-terminus of Rav1 and primers from YCR2-1 to YCR2-6 were used to construct FLAG tag to C-terminus of Rav2 (table 1). Yeast transformation method was used from Gietz R D and Woods RA [23].

Table 1. Oligonucleotides used in this study.

\begin{tabular}{|l|l|}
\hline $\begin{array}{c}\text { Oligonucleo- } \\
\text { tide name }\end{array}$ & \multicolumn{1}{c|}{ Oligonucleotide sequence 5' $\rightarrow$ 3' } \\
\hline YNR1-1 & TGCTGGCTGTTCAGAAGTTTTAG \\
\hline YNR1-2 & CAAGCTAAACAGATCTATATTACCATGGTAGCTAGTTGTAAAGATCAG \\
\hline YNR1-3 & CTGATCTTTACAACTAGCTACCATGGTAATATAGATCTGTTTAGCTTG \\
\hline YNR1-4 & GTGCGTTTGTAGATATCAAAGAATTAGAAAAACTCATCGAGCATC \\
\hline YNR1-5 & GATGCTCGATGAGTTTTTCTAATTCTTTGATATCTACAAACGCAC \\
\hline YNR1-6 & CTTGTCGTCATCGTCTTTGTAGTCCATGAGAACTACCTTTGCGTGTGC \\
\hline YNR1-7 & ATGGACTACAAAGACGATGACGACAAGTCATTGAACTTTCTTCCAGG \\
\hline YNR1-8 & CTAACTCATTATCAGAAGACCATC \\
\hline NR1-1 & GGACAAACCGAATAAAAGAGC \\
\hline NR1-2 & TCGTACTTCCCAATACTGACTATC \\
\hline YCR1-1 & ATTACCTGGCGGTTTCACTTG \\
\hline
\end{tabular}




\begin{tabular}{|l|l|}
\hline YCR1-2 & $\begin{array}{l}\text { CTACTTGTCATCGTCGTCCTTGTAATCAGCTACAAAGTCATCTAG- } \\
\text { TAAGTTCTTGG }\end{array}$ \\
\hline YCR1-3 & GCTGATTACAAGGACGACGATGACAAGTAGGCGCCACTTCTAAATAAGCG \\
\hline YCR1-4 & ATCAAAGAATCTGGGACGCTC \\
\hline CR1-1 & ATTGGATCTCTAAATGTTGAAGCA \\
\hline CR1-2 & AACTATGGGTGTCCCGCTT \\
\hline YCR2-1 & GGTGACTAAAAAACCTTGG \\
\hline YCR2-2 & TTACTTGTCATCGTCGTCCTTGTAGTCCTTATATGTACTTAACTGTTTGCTA \\
\hline YCR2-3 & GACTACAAGGACGACGATGACAAGTAAAATTTCTTATGATTTATGATTTTTA \\
\hline YCR2-4 & GTTAATGTTATCGCTAGTAGAGCGGCGTTAGTATCGAATC \\
\hline YCR2-5 & GCTGTCGATTCGATACTAACGCCGCTCTACTAGCGATAACATTAACA \\
\hline YCR2-6 & ATTAGATTTGATTGAAGAG \\
\hline CR2-1 & CTTTGTAGGAATGAGCTTTGC \\
\hline CR2-2 & AGTTCCCGAATATGATGTTG \\
\hline
\end{tabular}

\subsection{Genomic DNA extraction}

Yeast strain was incubated overnight at OD600 approximately 10 in YPD medium, $30^{\circ} \mathrm{C}$, $200 \mathrm{rpm} .3 \mathrm{~mL}$ samples were collected by centrifugation at 8,000 xg for 2 minutes. Wash the cells with sterile water and resupend the cells in $500 \mu \mathrm{l}$ of sorbitol solution $(0.9 \mathrm{M}$ sorbitol, 0.1 $\mathrm{M}$ Tris- $\mathrm{HCl}, 10 \mathrm{mM}$ EDTA, $\mathrm{pH}$ 7.5). Add $1 \mu \mathrm{l} \beta$-mercaptoethanol and $20-50 \mu \mathrm{L}$ stock solution of lyticase $(1,000 \mathrm{U} / \mathrm{ml})$. Incubate at $37{ }^{\circ} \mathrm{C}$ for 3 hours to achieve $80 \%$ spheroplasting, centrifuged at $8,000 \mathrm{xg}$ for 5 minutes then resuspended in $500 \mu \mathrm{l}$ TE (10 mM Tris, $1 \mathrm{mM}$ EDTA) (pH8.0). Add $50 \mu \mathrm{l} 10 \%$ SDS and $10 \mu \mathrm{l}$ proteinase $\mathrm{K}(10 \mathrm{mg} / \mathrm{ml})$. Incubate at $65^{\circ} \mathrm{C}$ for 20 minutes. Add $10 \mu \mathrm{l} \mathrm{RNaseA}(10 \mathrm{mg} / \mathrm{ml})$ and incubate $37^{\circ} \mathrm{C}$ for 1 hour. Add $550 \mu \mathrm{L}$ chloroform:isoamyl alcohol (24:1), vortex, then centrifuge. Precipitate DNA with isopropanol (volume ratio $1: 1$ ), place on dry ice for 10 minutes or at $-20{ }^{\circ} \mathrm{C}$ for 1 hour. Centrifuge at $15,000 \mathrm{xg}$ for 10 minutes at $4{ }^{\circ} \mathrm{C}$. Wash twice with $70 \%$ methanol. Dry the pellets and resuspend the DNA in $50 \mu \mathrm{l}$ of TE or $\mathrm{ddH}_{2} \mathrm{O}$. Test the result with agarose gel electrophoresis.

\subsection{RAVE complex purification}

RAVE complex was purified from three yeast strains. BY4742 FLAG-Rav1 strain has FLAG tag which was introduced into the N terminus of Rav1 gene of $S$. cerevisiae BY4742, BY4742 Rav1-FLAG strain has FLAG tag which was introduced into the C terminus of Rav1 gene of $S$. cerevisiae BY4742 and BY4742 Rav2-FLAG with FLAG tag was introduced into the C terminus of Rav2 gene of $S$. cerevisiae BY4742. Yeast strain was grown in $50 \mathrm{ml}$ YEPD medium overnight to $\mathrm{A}_{600 \mathrm{~nm}}$ of around 3 , and add $50 \mathrm{ml}$ of this culture was added 1 litre of YEPD media in a 3 liter Fernbach flask (total volume for one time purify is 8 liters). The flasks were incubated at $30{ }^{\circ} \mathrm{C}$ under vigorous shaking until an $\mathrm{A}_{600 \mathrm{~nm}}$ of around 3 (early log phase). Yeast was harvested by centrifugation, washing and resuspended TBSE $(50 \mathrm{mM}$ Tris- $\mathrm{HCl}, 150 \mathrm{mM}$ $\mathrm{NaCl}, 1 \mathrm{mM}$ EDTA, $\mathrm{pH}$ 7.4) and the protease inhibitor (at $1 \mathrm{mM}$ phenylmethylsulfonyl fluoride) were added shortly before cells were lysed by two passages through a French pressure cell at 25,000 p.s.i. The cell lysate was centrifuged at $20,000 \mathrm{xg}$ for 20 minutes at $4{ }^{\circ} \mathrm{C}$. The supernatant, 
was achieved after centrifugation, is loaded onto a small column contained $1 \mathrm{ml}$ of anti-FLAG M2 gel. The anti-FLAG column was washed with 20 column volumes of TBSE, and RAVE complex was eluted with TBSE containing $100 \mu \mathrm{g} / \mathrm{ml}$ FLAG peptides.

\subsection{Western blot}

After separation by SDS-PAGE, proteins were transferred onto a $0.45 \mu \mathrm{m}$ PVDF membrane, using electron transport. Then, the membrane was washed three times ( 5 minutes each time) with TBS (10 mM Tris/Cl, $150 \mathrm{mM} \mathrm{NaCl}, \mathrm{pH}$ 7.4). The membrane was blocked with $3 \%$ bovine serum albumin in TBST ( $10 \mathrm{mM}$ Tris/Cl, $150 \mathrm{mM} \mathrm{NaCl}, \mathrm{pH} 7.4,0.01 \%$ Tween 20$)$ for 2 hours at room temperature. Then it was incubated with anti-FLAG tag monoclonal antibody (1: 2,000 in TBST) overnight at $4{ }^{\circ} \mathrm{C}$. The membrane was washed three times (10 minutes each time) with TBST and incubated with HRP AffiniPure Goat Anti-Mouse IgG (1:1000 in TBST) for 1h at $37{ }^{\circ} \mathrm{C}$. Finally, the membrane was washed three times with TBST and once with TSB. The result was show with diaminobenzidine (DAB).

\section{RESULTS}

\subsection{Constructed recombinant strains}

We constructed three strains, strain 1 which contained FLAG tag at N-terminus of Rav1, strain 2 with FLAG tag at C-terminus of Rav1 and strain 3 with FLAG tag at C-terminus of Rav2. The method from Lorenz et al [24] was partially modified and used in this study. For constructing FLAG tag to N-terminus of Rav1, first, four fragments were synthesized by PCR (Fig. 2a). Fragment 1 (using primers YNR1-1 and YNR1-2), fragment 3 (using primers YNR1-5 and YNR1-6) and fragment 4 (using primers YNR1-7 and YNR1-8) are homogeneous with S. cerevisiae genome, and fragment 4 is the 5'-end of Rav1 with FLAG tag DNA sequence inserted in after the start codon of Rav1. Fragment 2 (using primers YNR1-3 and YNR1-4) contains KanMX6 marker. Primers YNR1-1 and YNR1-8 were used to fuse these 4 fragments (Fig. 2b). After that, fusion PCR products were used to transform to S. cerevisiae BY4742. Recombinant strains were screened on YEPD medium containing $200 \mu \mathrm{g} / \mathrm{ml} \mathrm{G418}$. Furthermore, PCR was performed by using primers NR1-1 and NR1-2 to test for integration of constructing FLAG tag to the 5'-end of Rav1 and the PCR product was sequenced for confirmation (Fig. 2c). The resulted-recombinant strain was named S. cerevisiae BY4742 FLAG-RAV1.

For constructing FLAG tag to C-terminus of Rav1, two fragments were synthesized by PCR (Fig. 3a). Fragment 1 (using primers YCR1-1 and YCR1-2) is the 3'-end of Rav1 with FLAG tag DNA sequence inserted before the stop codon of Rav1. Fragment 2 (using primers YCR1-3 and YCR1-4) contains KanMX6 marker and homogenes of S. cerevisiae genome. The results of fusion PCR product using these fragments are shown in Fig. 3b. And test for integration of constructing FLAG tag to the 3'-end of Rav1 by PCR using primers CR1-1 and CR1-2 are shown in Fig. 3c. Then recombinant strain was confirmed by DNA sequencing. Finally, S. cerevisiae BY4742 RAVI-FLAG was achieved.

For constructing FLAG tag to C-terminus of Rav2, three fragments were synthesized by PCR (Fig. 4a). Fragment 1 (using primers YCR2-1 and YCR2-2)and fragment 3 (using primers YCR2-5 and YCR2-6) are homogeneous with S. cerevisiae genome, and fragment 1 is the 3'end of Rav2 with FLAG tag DNA sequence inserted before the stop codon of Rav2. Fragment 2 (using primers YCR2-3 and YCR2-4) contains KanMX6 marker. The results of fusion PCR 
product using these fragments were shown in Fig. 4b. Furthermore, PCR was performed by using primers CR2-1 and CR2-2 to test for integration of constructing FLAG tag to the 3'-end of Rav2 and the PCR product was sequenced for confirmation (Fig. 4c). The achieved strain was named S. cerevisiae BY4742 RAV2-FLAG.

$\underline{a}$

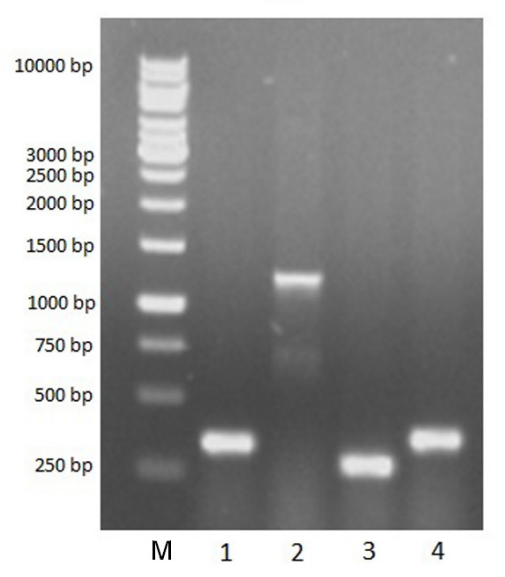

$\underline{\mathbf{b}}$

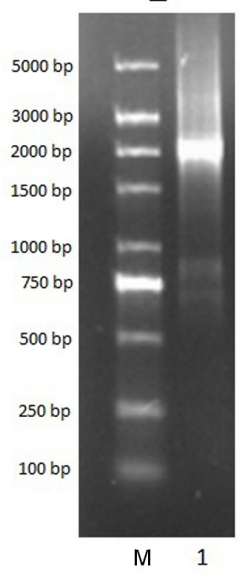

c

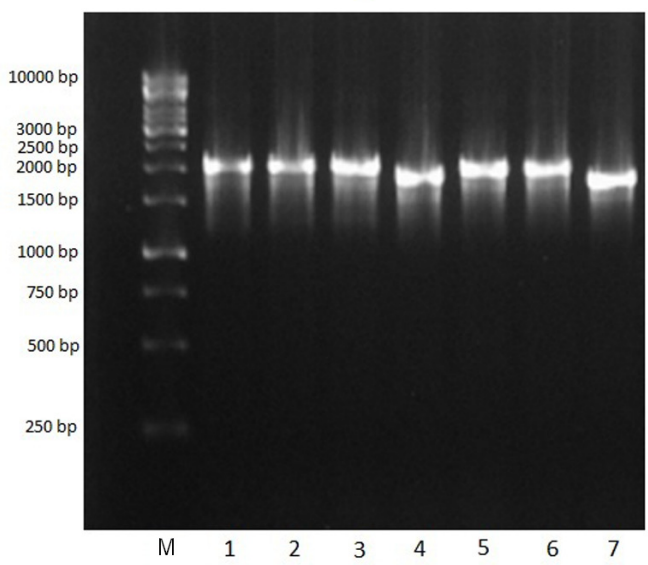

Figure 2. The S. cerevisiae BY4742 FLAG-RAVI constructed

(a) Land 1: Fragment 1 using primers YNR1-1 and YNR1-2 for PCR, land 2: Fragment 2 using primer YNR1-3 and YNR1-4 for PCR, Land 3: Fragment 3 using primers YNR1-5 and YNR1-6 for PCR, Land 4: Fragment 4 using primers YNR1-7 and YNR1-8 for PCR, land M: GeneRuler 1kb DNA Ladder.

(b) Land 1: Fusion PCR products of 4 fragments using primers YNR1-1 and YNR1-8.

(c) Lands 1 to 7: Test for integration of constructing FLAG tag to the N-terminal of Rav1 using primers NR1-1 and NR1-2 of 7 strains.

a

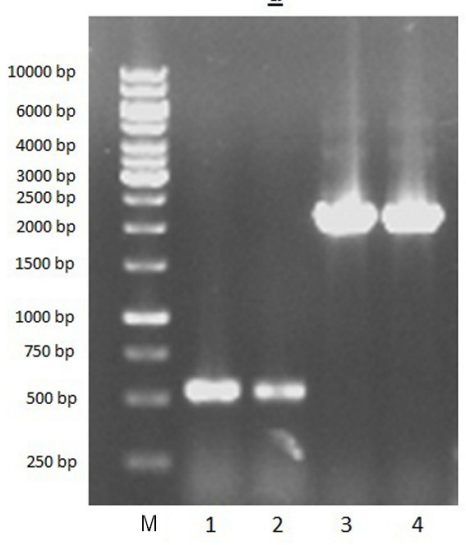

$\underline{\mathbf{b}}$

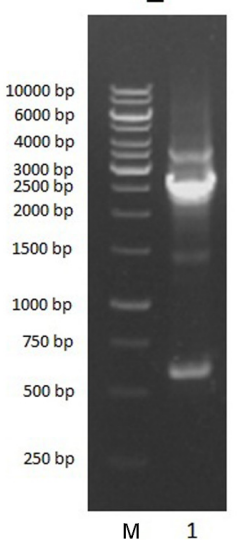

$\underline{c}$

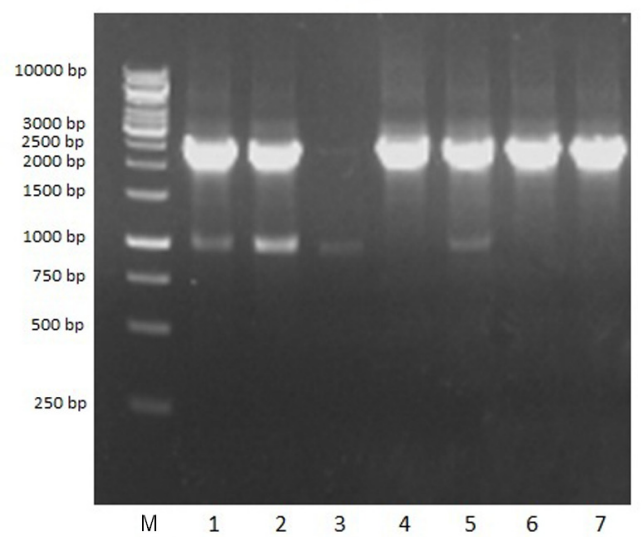

Figure 3. The S. cerevisiae BY4742 RAV1-FLAG constructed.

(a) Land 1 and 2: Fragment 1 using primers YCR1-1 and YCR1-2 for PCR, land 3 and 4: Fragment 2 using primer YCR1-3 and YCR1-4 for PCR, land M: GeneRuler 1kb DNA Ladder. (b) Land 1: Fusion PCR products of 2 fragments using primers YCR1-1 and YCR1-4. (c) Lands 1 to 7: Test for integration of constructing FLAG tag to the C-terminal of Rav1 using primers CR1-1 and CR1-2 of 7 strains. 

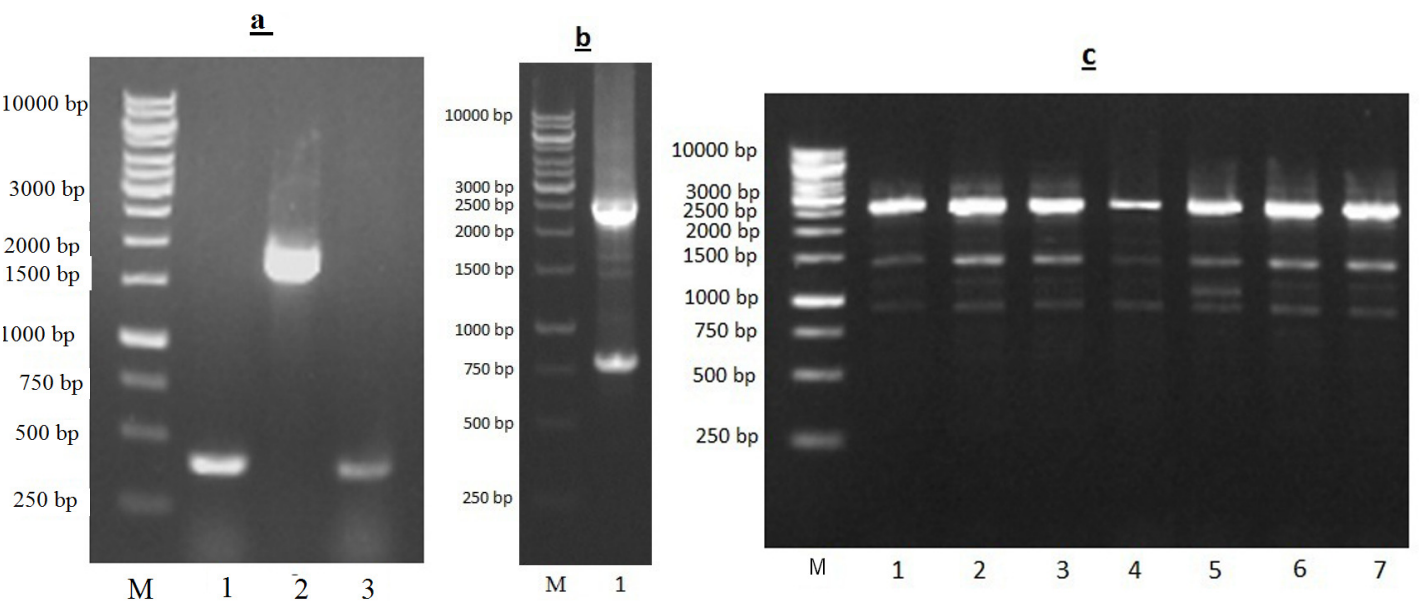

Figure 4. The S. cerevisiae BY4742 RAV2-FLAG constructed.

(a) Land 1: Fragment 1 using primers YCR2-1 and YCR2-2 for PCR, land 2: Fragment 2 using primer YCR2-3 and YCR2-4 for PCR, Land 3: Fragment 3 using primers YCR2-5 and YCR2-6 for PCR, land M: GeneRuler 1kb DNA Ladder. (b) Land 1: Fusion PCR products of 3 fragments using primers YCR2-1 and YCR2-6. (c) Lands 1 to 7: Test for integration of constructing FLAG tag to the C-terminal of Rav2 using primers CR2-1 and CR2-2 of 7 strains.

\subsection{Purification of rave complex}

For purifying RAVE complex, we chose FLAG tag, due to it is two necessary characteristics: protein purification with high purity and little opportunity to impair tagged protein structure (FLAG tag has 8 amino acids, so the size of FLAG tag is small), additionally, FLAG tag can be removed by enterokinase. With another tag, if they can bring high purity to protein purification like Staphylococcus protein A (58 amino acids) or Streptavidin-binding peptide (38 amino acids), they may impair the tagged protein structure because, normally, they have big size. If they has small size and a little impair to structure of tagged protein, they may provide poor purity to protein purification [25].

In the Fig. 5, the band of the protein was not big which may attribute the low protein concentration. The low concentration of RAVE in yeast might be due to the reason that RAVE complex was a regulation factor which necessarily may not remain in large amounts in the cell. Comparatively seen in SDS-PAGE Fig. 5a (RAVE complex was purified from BY4742 FLAG$R A V 1$ ), 5b (RAVE complex was purified from BY4742 RAV1-FLAG) and 5c (RAVE complex was purified from BY4742 RAV2-FLAG), the efficiency of purification using strains BY4742 FLAG-RAV1 and BY4742 RAV1-FLAG were almost the same, but RAVE complex purification using strain BY4742 RAV2-FLAG was better. Beside three bands are Rav1p, Rav2p and Skp1p, there were other bands of $95 \mathrm{kDA}, 72 \mathrm{kDA}$ and $55 \mathrm{kDa}$. 


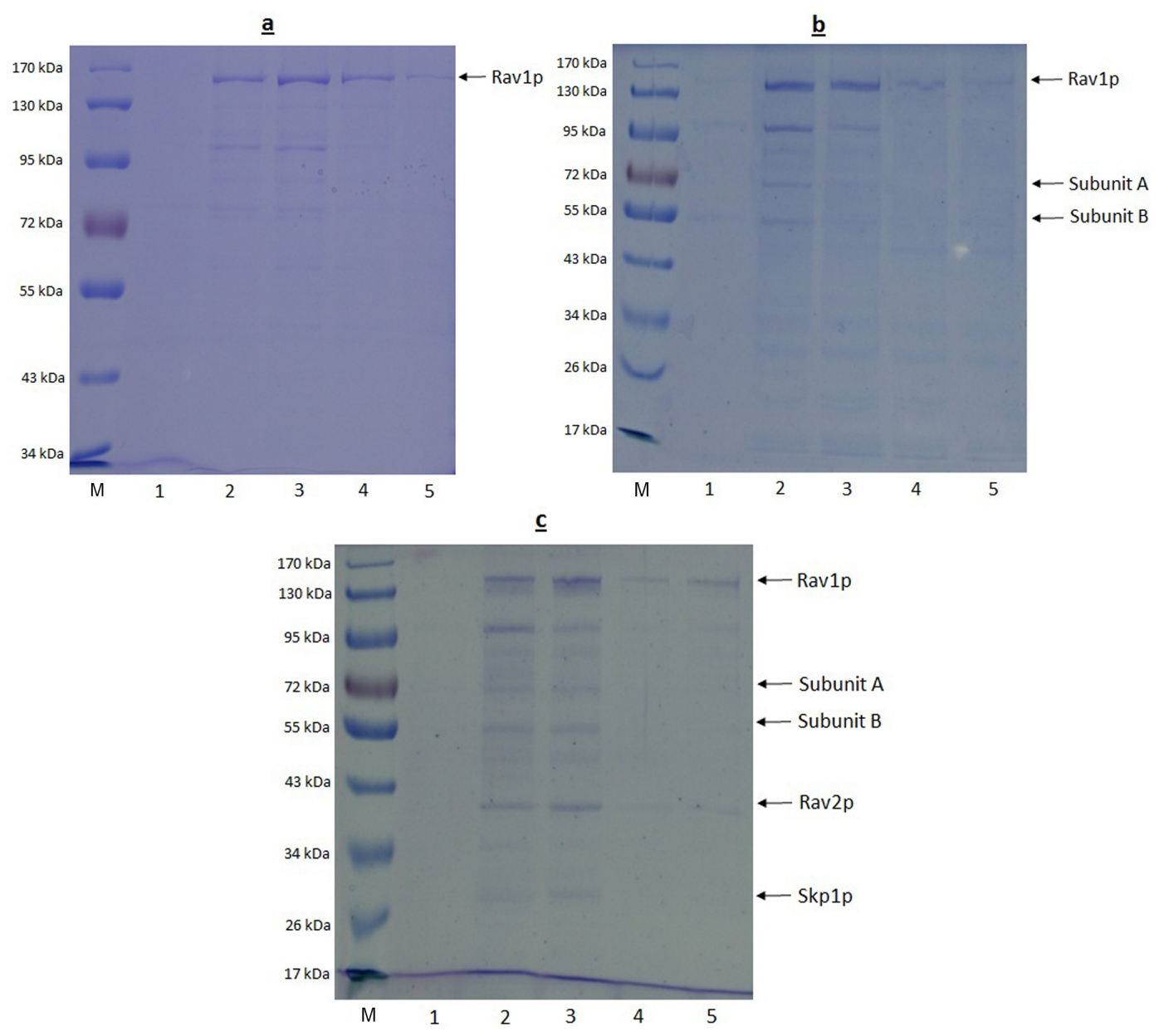

Figure 5. SDS-PAGE of RAVE complex purification.

a) RAVE complex purification from BY4742 FLAG-RAV1. From land 1 to 5: RAVE complex eluted from anti-FLAG affinity column at fraction from 1 to 5 respectively, land M: PageRuler Prestained Protein Ladder

b) RAVE complex purification from BY4742 RAVI-FLAG. From land 1 to 5: RAVE complex eluted from anti-FLAG affinity column at fraction from 1 to 5 respectively.

c) RAVE complex purification from BY4742 RAV2-FLAG. From land 1 to 5: RAVE complex eluted from anti-FLAG affinity column at fraction from 1 to 5 respectively.

The subunit $\mathrm{A}$ of $\mathrm{V}_{1}$ domain may present at $72 \mathrm{kDa}$ site, and the subunit $\mathrm{B}$ of $\mathrm{V}_{1}$ domain may present at $55 \mathrm{kDa}$ site [17]. From the results of Western blot, shown in Fig. 6a and 6b, Rav1p is not stable, can be degraded to 6 fragments, respectively with 6 bands in Fig. 6b. So the band at $95 \mathrm{kDa}$ site can be a fragment of Rav1p or be a other protein. To confirming this sequencing of protein band is necessary. In Fig. 6c, it is showed Rav2p is stable and easy digested, this is sensible. Because the expression of Rav1p is toxic to yeast [26], so degradation of Rav1p may occur due to it is protease enzyme in cytoplasm of yeast. 


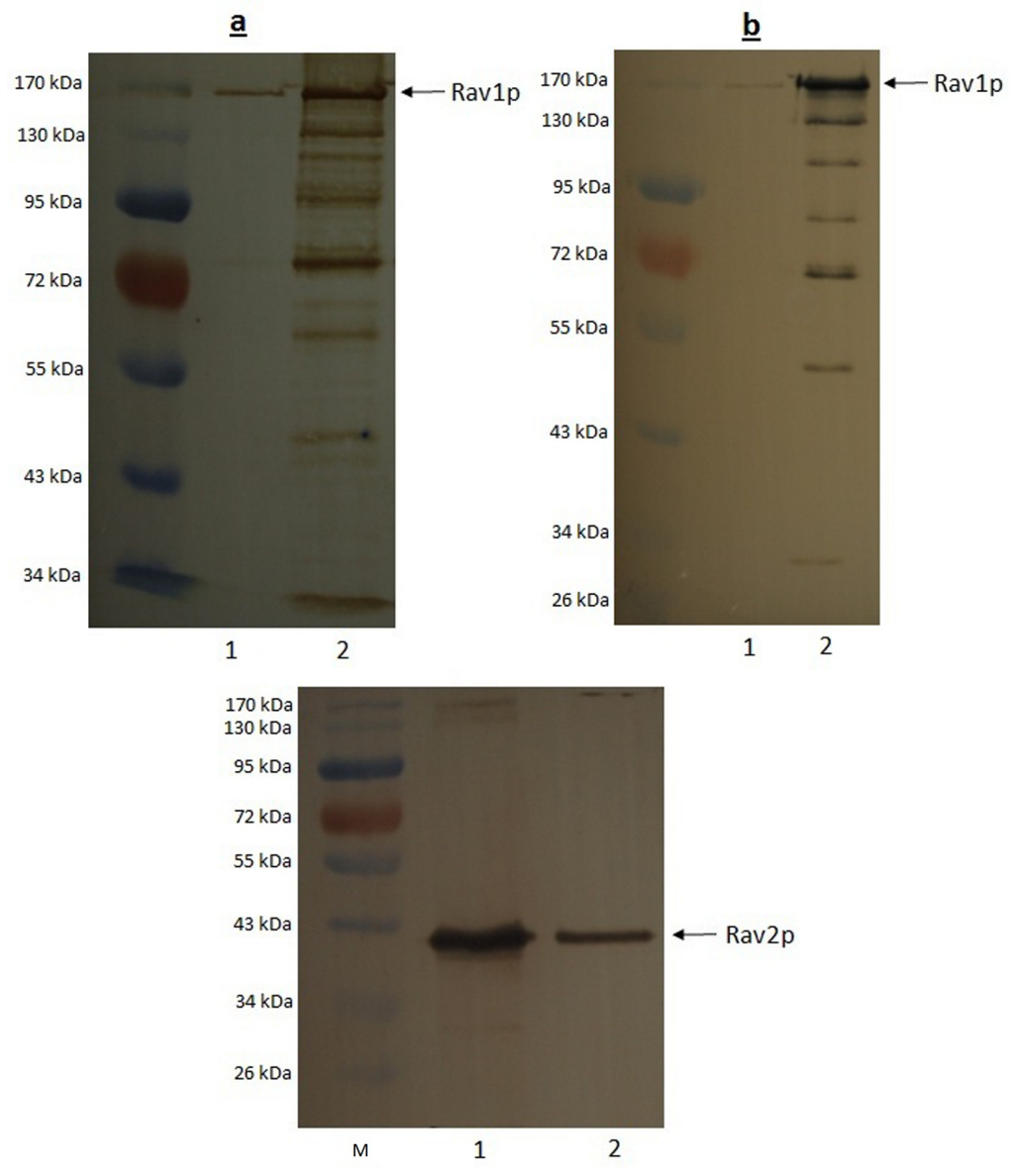

Figure 6. Western blots of extracted proteins.

(a) Western blot of RAVE complex extracted from BY4742 FLAG-RAV1 with FLAG tag fused to Nterminus of Rav1. Land 1: Fraction 1 of RAVE complex elution. Land 2: Fraction 2 of RAVE complex elution. Land M: PageRuler Prestained Protein Ladder. (b) Western blot of RAVE complex extracted from BY4742 RAV1-FLAG with FLAG tag fused to C-terminus of Rav1. Land 1: Fraction 1 of RAVE complex elution. Land 2: Fraction 2 of RAVE complex elution. (c) Western blot of RAVE complex extracted from BY4742 RAV2-FLAG with FLAG tag fused to C-terminus of Rav2. Land 1: Fraction 1 of RAVE complex elution. Land 2: Fraction 2 of RAVE complex elution.

\section{CONCLUSION}

The purification of RAVE complex is not only supports 3-D structure determination but also supports for in vitro or in vivo studies of V-ATPase regulation. So it necessary removes all other proteins out of RAVE complex. To perform this, we should find some condition to release them to RAVE complex. Thus that investigation can helps us understand more about the interaction of RAVE complex and subunits of V-ATPase.

Acknowlegements. The fund was supplied by the National Natural Science Foundation (30800018); the National Natural Science Foundation (30970058); Doctoral Program of Higher Specialized Research Fund 
(200802951036); the Industrial Biotechnology, Ministry of Education Key Laboratory Director Fund (KLIB-ZR200801).

\section{REFERENCES}

1. Jefferies K. C, Cipriano D. J, Forgac M. - Function, structure and regulation of the vacuolar $\mathrm{H}^{+}$-ATPases, Archives of Biochemistry and Biophysics 476 (1) (2008) 33-42.

2. Forgac M. - Vacuolar ATPases: rotary proton pumps in physiology and pathophysiology, Nature reviews Molecular Cell Biology 8 (11) (2007) 917-929.

3. Kane P. M, Smardon A. M. - Assembly and regulation of the yeast vacuolar $\mathrm{H}^{+-}$ATPase, Journal of Bioenergetics and Biomembranes 35 (4) (2003) 313-321.

4. Toei M., Saum R., Forgac M. - Regulation and isoform function of the V-ATPases, Biochemistry 49 (23) (2010) 4715-4723.

5. Baars T. L., Petri S., Peters C., Mayer A. - Role of the V-ATPase in regulation of the vacuolar fission-fusion equilibrium, Molecular Biology of the Cell 18 (10) (2007) 38733882.

6. Morel N. - Neurotransmitter release: the dark side of the vacuolar $\mathrm{H}^{+}$-ATPase, Biology of the Cell 95 (7) (2003) 453-457.

7. Dettmer J., Hong-Hermesdorf A., Stierhof Y. D., Schumacher K. - Vacuolar H+ $\mathrm{H}^{+}$ATPase activity is required for endocytic and secretory trafficking in Arabidopsis, The Plant Cell 18 (3) (2006) 715-730.

8. Oka T., Futai M. - Requirement of V-ATPase for ovulation and embryogenesis in Caenorhabditis elegans, The Journal of Biological Chemistry 275 (38) (2000) 2955629561.

9. Hunt S. R., Hernandez R., Brown D. T. - Role of the vacuolar-ATPase in Sindbis virus infection, Journal of Virology 85 (3) (2010) 1257-1266.

10. Mario P. S., Abel G. G., Maria D. R. L., Pilar G. V. - Role of V-ATPases in solid tumors: Importance of the subunit C (review), International Journal of Oncology 34 (6) (2009).

11. Sennoune S. R., Bakunts K., Martinez G. M., Chua-Tuan J. L., Kebir Y., Attaya M. N., Martinez-Zaguilan R. - Vacuolar $\mathrm{H}^{+}$-ATPase in human breast cancer cells with distinct metastatic potential: distribution and functional activity, American Journal of Physiology Cell Physiology 286 (6) (2004) C1443-1452.

12. Williamson W. R., Hiesinger P. R. - On the role of V-ATPase V0a1-dependent degradation in Alzheimer disease, Communicative \& Integrative Biology 3 (6) (2010) 604-607.

13. Forgac M. - Structure, mechanism and regulation of the clathrin-coated vesicle and yeast vacuolar $\mathrm{H}^{+}$-ATPases, The Journal of Experimental Biology 203 (1999) 71-80.

14. Kane P. M. - The where, when, and how of organelle acidification by the yeast vacuolar H+-ATPase, Microbiology and Molecular Biology reviews: MMBR 70 (1) (2006) 177191.

15. Zhang Z., Charsky C., Kane P. M, Wilkens S. - Yeast V1-ATPase: affinity purification and structural features by electron microscopy, The Journal of Biological Chemistry 278 (47) (2003) 47299-47306. 
16. Zhang Z., Zheng Y., Mazon H., Milgrom E., Kitagawa N., Kish-Trier E., Heck A. J, Kane P. M, Wilkens S. - Structure of the yeast vacuolar ATPase, The Journal of Biological Chemistry 283 (51) (2008) 35983-35995.

17. Seol J. H., Shevchenko A., Shevchenko A., Deshaies R. - Skp1 forms multiple protein complexes, including RAVE, a regulator of V-ATPase assembly, Nature Cell Biology $\mathbf{3}$ (4) (2001) 384-391.

18. Smardon A. M., Tarsio M., Kane P. M. - The RAVE complex is essential for stable assembly of the yeast V-ATPase, The Journal of Biological Chemistry 277 (16) (2002)13831-13839.

19. Smardon A. M., Kane P. M. - RAVE is essential for the efficient assembly of the C subunit with the vacuolar $\mathrm{H}^{+}$-ATPase, The Journal of Biological Chemistry 282 (36) 26185-26194.

20. Connelly C., Hieter P. - Budding yeast Skp1 encodes an evolutionarily conserved kinetochore protein required for cell cycle progression, Cell 86 (2) (1996) 275-285.

21. Galibert Fea - Complete nucleotide sequence of Saccharomyces cerevisiae chromosome X, EMBO J. 15 (9) (1996) 2031-2049.

22. Jacq Cea - The nucleotide sequence of Saccharomyces cerevisiae chromosome IV, Nature 387 (6632 Suppl) (1997) 75-78.

23. Gietz R. D., Wood R. A. - Transformation of yeast by the LiAc/SS carrier DNA/PEG method, Methods in Enzymology 350 (2002) 87-96.

24. Lorenz M. C., Muir R. S., Lim E., McElver J., Weber S. C., Heitman J. - Gene disruption with PCR products in Saccharomyces cerevisiae, Gene 158 (1) (1995) 113-117.

25. Xu X., Song Y., Y. L., J. C, H. Z, L. A. - The tandem affinity purification method: an efficient system for protein complex purification and protein interaction identification, Protein Expression and Purification 72 (2) (2010) 149-156.

26. Brace E. J., Parkinson L. P., Fuller R. S. - Skp1p regulates Soi3p/Rav1p association with endosomal membranes but is not required for vacuolar ATPase assembly, Eukaryotic Cell $\mathbf{5}$ (12) (2006) 2104-2113.

\section{TÓM TĂT}

\section{TINH SẠCH PHỨC HỢP RAVE TỬ SACCHAROMYCES CEREVISIAE BẰNG VIỆC SỬ DỤNG FLAG TAG}

Nguyễn Thành Chung ${ }^{1, *}$, Phạm Thị Tâm ${ }^{1}$, Tạ Thị Thu Thủy ${ }^{1}$, Chunyin Gu$^{2}$, Zhenyu Zhang ${ }^{2}$

${ }^{1}$ Khoa Công nghệ Sinh học, Viện Đại học Mở Hà Nội, Nhà B101 đường Nguyễn Hiền, Quận Hai Bà Trung, Hà Nội, Việt Nam

${ }^{2}$ The Key Laboratory of Industrial Biotechnology, Ministry of Education, Jiangnan University, No. 1800 Lihu Avenue, Wuxi, Jiangsu, 214122, China

*Email:ngthachung@gmail.com

RAVE (Regulator of the H+-ATPase of the Vacuolar and Endosomal membranes) là một nhân tố cần thiết cho quá trình lắp ráp và tái lắp ráp của V-ATPase. Phức hợp RAVE có ba tiểu đơn vị đó là: Rav1p, Rav2p và Skp1p. Hiện nay có rất ít những nghiên cứu về phức hợp RAVE. 
Vì vậy việc nghiên cứu cấu trúc của phức hợp RAVE là rất quan trọng để hiểu rõ về quá trình điều hòa sự lắp ráp cũng như là tái lắp ráp của $\mathrm{V}$-ATPase. Trong nghiên cứu này, phức hợp RAVE được tinh sạch bằng ái lực, dựa vào việc gắn FLAG tag vào tiểu đơn vị Ravlp hoặc là Rav2p. Quá trình thí nghiệm: Tế bào nấm men được nuôi trong 8 lít môi trường lỏng YEPD ở $30{ }^{\circ} \mathrm{C}$, lắc ở $200 \mathrm{rpm}$, cho đến khi $\mathrm{OD}_{600 \mathrm{~nm}}$ khoảng 3 . Sau đó tế bào sẽ được phá vỡ bằng thiết bị French pressure cell disruptor ở 25000 p.s.i trong đệm TBSE $(50 \mathrm{mM}$ Tris/Cl, $150 \mathrm{mM} \mathrm{NaCl}, 1$ mM EDTA, pH 7,4) với $1 \mathrm{mM}$ PMSF. Dịch tế bào sau khi được phá vỡ sẽ được ly tâm ở 20000 xg trong 20 phút ở $4^{\circ} \mathrm{C}$. Tiếp theo, toàn bộ dịch nổi được chạy qua cột sắc ký có chứa $1 \mathrm{ml}$ anti-FLAG M2 gel. Sau khi rửa cột anti-FLAG với đệm TBSE, phức hợp RAVE sẽ được rửa giải với đệm TBSE có chứa $100 \mu \mathrm{g} / \mathrm{ml}$ FLAG peptides. Kết quả thu được chỉ ra rằng, việc tinh sạch phức hợp RAVE bằng cách gắn FLAG tag vào đầu $\mathrm{C}$ của dưới đơn vị Rav2 từ nấm men $S$. cerevisiae tốt hơn là khi tinh sạch phức hợp RAVE bằng cách gắn FLAG tag vào đầu $\mathrm{N}$ hoặc đầu $\mathrm{C}$ của dưới đơn vị Rav1.

Tù khóa: phức hợp RAVE, Rav1, Rav2, Skp1, V-ATPase, nấm men, tinh sạch protein. 